Скорук, Ірина. «Польські відапелятивні прізвища в антропоніміконі м. Луцька». Лінгвостилістичні студіï, вип. 11, 2019, с. 155-65.

Skoruk, Iryna. "Polish Surnames Motivated by Appellatives in the Anthroponymicon of Lutsk". Linguostylistic Studies, iss. 11, 2019, pp. 155-65.

УДК 811.161.2'373.232.1(477.82-25):811.162.1

https://doi.org/10.29038/2413-0923-2019-11-155-165

\title{
ПОЛЬСЬКІ ВІДАПЕЛЯТИВНІ ПРІЗВИЩА В АНТРОПОНІМІКОНІ М. ЛУЦЬКА
}

\author{
Ірина Скорук \\ Східноєвропейський національний університет імені Лесі Українки, \\ Луцьк, Україна
}

У статті проаналізовано польські відапелятивні прізвища, дібрані з метричних книг Державного архіву Волинської області й актових записів про народження Луцького міського рацсу. Виявлено, що прізвища відображають особливості навколишнього світу, побуту людей, суспільно-економічний та політичний лад, матеріальну культуру тогочасного суспільства, в якому вони виникли та функціонують як головний засіб офіційної ідентифікації родини в суспільстві. Дослідження семантики твірних основ антропонімних одиниць дає змогу зрозуміти специфіку антропонімікону м. Луцька.

Ключові слова: антропонім, прізвище, апелятив, відапелятивні прізвища, лексико-семантичні групи.

\section{POLISH SURNAMES MOTIVATED BY APPELLATIVES IN THE ANTHROPONYMICON OF LUTSK Iryna Skoruk}

Lesya Ukrainka Eastern European National University, Lutsk, Ukraine

Recently, the researchers have become increasingly interested in the studies of the regional anthroponymy, including surnames as one of the most relevant and topical linguistic issues. Surnames are considered mainly as a linguistic phenomenon in terms of linguistic and historical development, with a focus on their origin, surname appelative semantics, and specifics of name-formation patterns. The characteristic features of the economic, political, and cultural life of distant ancestors are elucidated via the case study of a surname origin. The author argues that specific features of the anthroponymic system may be associated with the linguistic interactions of those peoples who have lived in the same territory for a long time.

The article analyzes the Polish surnames motivated by the appelatives, which have been selected from the metric books of the State Archives of the Volyn region and act records of the birth of the Lutsk City Council. The methods of inventory, systematization, and the method of etymological analysis were used to identify the anthroponymic materials with the features specific for the Polish anthroponymy. The method of structural-semantic analysis allows the linguistic qualification of surnames according to their word-formation model. Two categories of anthroponyms are considered: surnames motivated by the personal name (nomina personalia), and surnames derived from appellations with non-personal meaning

(C) Скорук I., Східноєвропейський національний університет імені Лесі Українки, 2019.

Це стаття відкритого доступу на умовах СC BY-NC 4.0 
(nomina impersonalia). The key findings of the study prove that the culture of a society, in which surnames have occurred and live, is an effective way for the official identification of family in the society. The study of the anthroponymic units with a focus on their elements semantics contributes to a better understanding of the Lutsk anthroponymicon features.

Key words: anthroponym, surname, appellative, surnames motivated by appelatives, lexical-semantic groups.

Вступ. Вивчення регіональної антропонімії, зокрема й прізвищ, одне з найактуальніших мовознавчих досліджень. Прізвища розглядають переважно як мовне явище в аспекті лінгвістичного та історичного розвитку, досліджуючи в такий спосіб їх походження, допрізвищеву семантику та словотвірну специфіку. Водночас за їхніми твірними основами вивчають особливості економічного, політичного та культурного життя далеких предків.

Регіональний аспект дослідження передбачає не тільки структурносемантичний аналіз прізвищ, а й скеровує передусім на виявлення специфічних рис антропонімікону, що можуть бути пов'язані з мовними взаємовпливами тих народів, які тривалий час проживають на одній території. Тому на особливу увагу в цьому плані заслуговує й вивчення особливостей антропонімних систем народів, які здавна заселяли Україну. Наприклад, польські прізвища мешканців Дрогобича кінця XVIII - початку XIX століття на східнослов'янському лінгвокультурному тлі проаналізувала М. Абузарова. А вплив української мови на формування лексичного складу польської мови XIX ст., зокрема й польської антропонімії, описала Н. Совтис.

Одним із багатонаціональних міст України є Луцьк, а тому специфіка антропонімікону міста полягає насамперед у виявленні його мовних особливостей. М. Худаш зазначав, що, досліджуючи антропонімію, можна орієнтовно визначити національний склад населення, окреслити етнічні межі, спостерігати за фактами асиміляції. На етнічну належність, за словами мовознавця, найвиразніше «вказує саме фонетична й морфологічна структура особової назви» (13).

Важливим моментом нашого дослідження $є$ виявлення польських відапелятивних прізвищ та визначення за їхніми твірними основами різних лексико-семантичних груп. Мовознавці вважають, що важливим показником мовної належності антропоніма може бути його суфікс (якщо утворення морфологічного способу), але необхідно спершу звертати увагу на їхню фономорфемну структуру та географію побутування (Горпинич, i Корнієнко 132). А отже, для виокремлення польських прізвищ особливу увагу потрібно звертати на такі ознаки, як: 1) фонетичні риси, властиві польській мові або її діалектам; 2) твірна основа походить від лексеми, що функціонує або функціонувала в польській мові чи пї діалектах; 3) прізвищеві форманти, притаманні польській мові або їі діалектам.

Щоб визначити відмінні риси й апелятивної, і пропріальної лексики мов із різних мовних груп, зауважує М. Абузарова, не потрібно докладати 
особливих зусиль. Натомість значно складніше виокремити специфічні риси певної мови на тлі інших мов тієї ж групи (7). Для визначення диференційних ознак польської мови на тлі східнослов'янських (здебільшого української) застосовуємо грунтовні дослідження українського мовознавця Ю. Шевельова, що стосуються розвитку фонологічної системи української мови 3 елементами порівняння фонологічних систем інших слов'янських мов, зокрема польської. Ширше і грунтовніше відокремлення фонетичних рис польської та української мов здійснив М. Лесів (12-14).

Мета дослідження - за твірними основами з'ясувати допрізвищеву семантику засвідчених польських прізвищ i визначити їх лексикосемантичні групи.

Матеріал і методи дослідження. Матеріалом нашого дослідження $\epsilon$ польські відапелятивні прізвища, дібрані з метричних книг Державного архіву Волинської області й актових записів про народження Луцького міського рацсу.

Методами дослідження антропонімного матеріалу $\epsilon$ описовий, порівняльно-історичний і метод структурно-семантичного аналізу, за допомогою яких було здійснено лінгвістичну кваліфікацію відапелятивних прізвищ лучан за їхніми твірними основами. Застосовано також прийоми інвентаризації й систематизації для виявлення антропонімного матеріалу, його специфічних рис, характерних для польської антропонімії та й загалом для польської мови.

Джерела порівняльного аналізу: історико-етимологічний словник К. Римута «Прізвища поляків», «Словник відапелятивних прізвищ поляків» Л. Томчака, «Словник старопольських назв особових» (за ред. В. Ташицького), «Українсько-польський, польсько-український словник» М. Юрковського та В. Назарука, «Словник сучасних українських прізвищ» Ю. К. Редька, «Словарь української мови» Б. Д. Грінченка, історикоетимологічний словник П. П. Чучки «Прізвища закарпатських українців». У зазначених словниках знаходимо генезу аналізованих прізвищ.

Результати дослідження та дискусія. Спираючись на прізвищеві класифікації за семантикою твірних основ таких мовознавців, як Я. Бистронь, С. Роспонд, М. Л. Худаш, Ю. К. Редько (класифікації названих мовознавців мають багато спільного), дослідники за прізвищевими основами поділяють антропоніми переважно на дві основні групи відонімні та відапелятивні. Польські відапелятивні прізвища, як i українські, розподіляємо на лексико-семантичні групи за їхніми твірними основами. Розпізнаємо польські прізвища передусім за формальними ознаками (за дослідженням Ю. Шевельова та М. Лесіва). Наприклад:

- метатеза у праслов'янських *tort, *tolt, *tert, *telt (на польському мовному грунті розвинулися в -ro-/-rzo-, -ło-, -rze-, -łe-: Блонський);

- відсутність повноголосся: пор. пол. Groch і укр. Горох, пол. Mrozek і укр. Морозко, пол. Wróbel i poc. Воробей; 
- збереження носових голосних $\boldsymbol{e}, \boldsymbol{q}$ : пор. пол. Wąsowicz і укр. Вус, пол. Gołąb і укр. Голуб, пол. Dembicki і укр. Дубицький. В українській мові праслов'янський носовий голосний * (старослов. юс великий) перейшов у ротовий [u], носовий *е (старослов. юс малий) набув вигляду ['a]/[ja];

- розщеплення назального: Гемба, Заремба, Венско;

- палаталізація приголосних: 1) збереження [i] (що утворилося 3 праслов'янського *i) після палаталізованих приголосних (на відміну від українського [у] та відповідного ствердіння приголосних): пор. пол. Niemiłowicz - укр. Милий, пол. Łoziński і укр. Лозинський, пол. Wisniowski i укр. Вишневський; 2) диграф rz в позиції перед [е] або [у] як наслідок палаталізації: пор. пол. Grzybowski і укр. Грибовський, пол. Dobrzyniecki i укр. Добринський, пол. Rzymski - укр. Римський;

- ć у польській мові замість $\mathbf{t}$ в українській та російській (білоруська здебільшого зберігає с) як наслідок палаталізації: пор. пол. Maciejowski i укр. Матіїшин / Матвіїшин, пол. Cichowska і укр. Тихий, пол. Zapłaciński укр. Заплатинський;

- збереження звукосполучення dl, tl i dm: пор. пол. Mydło і укр. Мило, пол. Sadłowski і укр. Салоїд. У східнослов’янських мовах збіги приголосних $\mathrm{tl}, \mathrm{dl} \mathrm{i} \mathrm{dm}$ втратили перший компонент (за винятком пізніших польських запозичень);

- dź в польській мові замість d в українській: пор. пол. Dziczka і укр. Дичко, пол. Dudziak і укр. Дудяк, пол. Niedzielski і укр. Недільський;

- польське [a] та [e] замість укр. [i] (в російській та білоруській [е]) на місці праслов'янського дифтонга *ie, що позначався літерою ь: пол. Rzezanka і укр. Різник, пол. Pogorzelec і укр. Погорілець, пол. Białecki і укр. Білецький;

- польське [g], що виникло на місці праслов'янського *g, замість укр. [h]: пор. пол. Bogdanowna і укр. Богдан, пол. Gruszka і укр. Грушка.

- збереження [e] перед зубними й губними приголосними та поява йотованого перед [e]: пол. Jemiłowicz - укр. Омелівський (jemioła - укр. омела), пол. Jezierski - укр. Озерський. А отже, в українській мові [е] змінилося на [о], а також немає йотованого;

- rz у кінці слова або складу, замість українського $\mathbf{r}$ (хоча на ствердіння українського $\mathrm{r}$ якраз вплинула польська фонетика): пор. пол. Pisarz - укр. Писар, пол. Gorzki - укр. Гіркий.

У групі відапелятивних прізвищ розглядаємо два розряди антропонімів: прізвища, мотивовані основами зі значенням особи (nотіna personalia), та прізвища, мотивовані основами 3 неособовим значенням (nomina impersonalia). Такий поділ враховує специфіку онімізації антропонімів: апелятивам із особовим значенням на момент переходу в оніми вже було властиве особове значення, натомість апелятиви 3 неособовим значенням мали переносне метафоричне або метонімічне значення. Як зауважував П. Чучка, шлях переходу апелятива групи nomina impersonalia в антропоніми удвічі довший, ніж особового: спочатку 
неособова назва мусить метафоризуватися і стати особовим апелятивом, а тільки тоді вже цей особовий апелятив може стати антропонімом (Чучка, Антропонімія 366).

3 особовими апелятивами співвідносні прізвища таких лексикосемантичних груп: назви осіб за індивідуальними ознаками; назви осіб за професією, заняттям; назви осіб за національністю; назви осіб за місцем проживання; назви осіб за соціальним станом; назви осіб за їхніми родинними стосунками.

\section{Прізвища, похідні від назв професій, посад, військової служби}

Прізвища цієї групи утворені переважно від назв професій, популярних і важливих в тогочасному суспільстві, але забутих на сьогодні. Апелятиви цієї групи умовно можна поділити на такі підгрупи: 1) назви професій (flis, krawiec, szewc, tkacz і т. д.); 2) назви адміністративних посад або належності до певних соціальних верств (kmieć, wozny, wójt тощо), 3) назви військових посад (chorążyk, sotnik, ułan).

Баца < baca 'старший чабан'; Дзяло < działo 'гармата'; Карчмарик, Качмар < karczmar 'корчма'; Ксендз, Ксендзюк < ksiqndz / ксьондз 'католицький священник'; Ляснік < las 'ліс'; укр. відповідник Лісник; Мисливий < туśliwy 'мисливець'; Тлумач (укр. Толмач) < tłuтасz 'перекладач'; Цесля - cieśla 'тесляр, тесля'; Bondarowicz < веdnarz 'майстер, який виготовляв дерев'яні вироби'; Chorqż̇yk < chorq̨ży / хорунжий 'особа, що носила прапор або корогву війська'; Flisowicz < flis 'особа, котра переправляла деревину річковим шляхом'; Gaydus < старопол gajda 'волинка'; ймовірно, особа, яка грала на волинці; Haydziak < hajda 'пастух у горах'; Humen <ihumen, humien / ігумен 'настоятель монастиря східного обряду'; Kmieć, Kmieciow < kmieć 'заможний господар'; у XIV-XV ст. лексема позначала селян, власників невеликих господарств; пор. Кмет < кмет 'селянин, господар, тямуща людина' (Чучка, Прізвища 269); Kowal, Kowalski < kowal 'коваль'; Kozakow, Kozaken, Kozakiewicz < kozak 'вільні люди, що вели боротьбу проти загарбників; представники війська'. Слово kozak також позначало жителя давньої України.

Krawczyk (Krawczykow) - від основи kraw-: 1) krawiec 'кравець'; 2) krawać (obcinac) 'обрізати'; Krayczyk (Krayczykowa) < krajczy 'кравець'; Kroli, Kruleck < król 'король'; Kuchta < kuchta 'кухар/кухарка' або 'помічник кухаря'; Pisarz < pisarz 'писар'; Ratay (Rataja, Ratajow, < rataj 'найманий сільський працівник'; Szewcowa <szewc 'швець'; Skotniec - похідне від прикметника skotny або іменника skotnik 'слуга, що випасає княжу худобу'; Slusarczyk, Szlusak < ślusarz, старопол. ślusar 'ремісник, котрий виробляє дрібні предмети з металу'; Solar (Solara, Solary), Solczak < solarz 'торговець сіллю'; Sołtak, Sołtyszczak < sołtys 'голова сільської адміністрації'; Stadnik < старопол. stadnik 'пастух кінського стада'; Stelmach, Stelmachowicz < stelmach 'ремісник, котрий виробляє дерев'яні частини для воза'; Wozniak (Wozniakiewicz) < woźny / возний 'судовий урядовець в Польщі до ХІХ ст.'; Zlesniczy < leśniczy 'лісничий'. 
Серед антропонімного матеріалу є прізвища з формантом -ik, - $y k$, які виконували демінутивну функцію, могли вказували на молоді чи малі істоти. Пізніше вони почали називати нащадків. Як зазначає К. Римут (Rymut 1:17), в XV ст. патронімні суфікси на -ic, -owicz були витіснені суфіксами -ik, -ek, -czak. Серед прізвищ цієї групи маємо значну кількість антропонімів на -(cz)yk. Поряд із ними трапляються фіксації з формантами -ek або -ес (назви професії у формі демінутивів). Наприклад, Kucharczyk Kucharek, Garbarczyk - Garbarek, Kowalczyk - Kowalek, Kołodziejczyk Kołodziejek, Borowczyk - Borowiec, Kaczmarczyk - Kaczmarek, Winiarczyk Winiarczek та ін.

\section{Прізвища, основи яких вказують на індивідуальні ознаки особи}

У цій групі прізвищ твірними основами $є$ апелятиви, що вказують на зовнішні ознаки (łysy, mały, szczupły), особливості певних частин тіла (gęba, kolano, kostka i т. д.), колір, відтінок (biały, blady, czarny), а також на особливості характеру, поведінки, мовлення тощо.

На особливості обличчя першоносія вказували такі прізвища: Геба < Gęba < gęba / губa 'той, що має великі губи, товстогубий, губастий' (Словарь 1:335); Венско, Wansiak, Wąsowicz < wq̨s 'вуса'; Глова, Гловяк < Głowa < głowa / голова 'той, що має велику чи розумну голову'; Broda, Brodowicz < broda / борода.

Голіброда - мотивоване однойменним прізвиськом-композитом, яке мав чоловік, котрий регулярно голив бороду.

Прізвища Kolano < kolano, Kostka < kostka вказували на особливість названих частин тіла у першоносія.

На інші індивідуальні особливості першоносія вказують такі прізвища: Бакусько - похідне з пол. Bakus, що утворене від старопол. bak 'крик', bakac 'кричати' (Rymut 1: 15); Бущер < bucerz 'гордовита людина'; Baлizypa < Waligóra 'Вернигора, назва великої незграбної людини' (Редько 1: 125); Заремба < zaręba 'молода, фізично здорова людина'; Кічкан < Kicać 'стрибати з присіданням до землі'. Пор. ще прізвища Kic, Kicko, Kickaj (Rymut 1:15); Liszczuk <liszeć 'робитися лихим' (Rymut 2: 22); Пекний < piękny 'красивий'; Białecki < biały 'білий’; Bladkow < blady 'блідий'; Chudzikiewicz < chudy 'худий'; Chydzik старопол. hydzić 'обмовляти, очорнювати' або діал. hydki 'бридкий'; Ciecienki - можливо, від cienki 'стрункий, делікатний'; Czarnecki < czarny 'чорний'; Garbicz < garb 'горб' або garbić się 'горбитися'; Gaydus < gajdus 'груба, незграбна людина'; Kędzierski, Kendziarek < kędzior 'локон', kędzierzawy 'кучерявий'; Kosmaty < kosmaty 'волосатий';

Kołtun, Kołtunowicz < kołtun / ковтун 'жмут збитого, брудного волосся на голові"; Lagodny < lagodny 'лагідний, сумирний, м'який'; Lewacz, Lewicki найімовірніше, від lewy 'лівий'; Łysiński, Łysinski <łysy 'той, що не мав волосся на голові'; Malik, Mal <mały 'малий'; Niemiłowicz, Niemiłowski < niemiły 'негарний, неприємний'; Paluszkiewicz - вірогідно, від 
зменшувального апелятива paluszek 'пальчик'; Pełech, Pelech, Peliszkiewicz < pełechaty / пелехатий 'людина з довгим скуйовдженим волоссям'.

Цікавими щодо твірної основи $\epsilon$ прізвиськового походження прізвища, утворені від апелятивів, що описують людину за ії психологічними особливостями (рисами характеру, способом розмови i поведінки, розумовими здібностями, улюбленою або частою дією, процесом, станом).

Злотко < zloto / золото; український відповідник Золотко; Мандрик < madry 'мудрий, розумний'; український відповідник Мудрик; Моцний < тоспу 'міцний' (напевно, сильний); Філозоф < fiłozof / філософ 'ймовірно, той, що любить думати про життя'; Ціхорська < Ціхор < ціхор, що походить від дієслова сzеchzać 'чесати', 'розчісувати' (Taszycki 595); Ціхоцький < czechzać 'чесати', 'розчісувати'; Gulkiewicz < gulać 'розважатися, веселитися'; Dziamski, Dziemski <dziama 'незграбна людина, нероба'; Kimakowicz < kimać 'дрімати'; Kner < knerać 'видавати звуки, властиві голубам'; Kukowna - від ап. kukać 'кувати, кукати'; Kunda < kunda 'гультяй, донжуан'; Łowicki < łowić 'ловити'; Lutak - від основи lut-: 1) luty 'злий'; 2) старопол. lutować się (litować się) 'змилосердитися';

Łuzecki < łuzać 'лускати'; Łykon < старопол. łygać 'говорити неправду'; Marnowska < marny 'бідний'; Masnowski < masny (tłusty) 'масний, жирний'; Przytuła < przytulić 'притулитися'; Skrypuchiewicz < skrzypieć 'скрипіти' з українським р замість rz; Skoryna, Skorynow < skory 'швидкий, охочий' або skóra 'шкіра'; Dziug, Dziugowicz < dziugać 'ковзатися, колисатися'; Nowak < nowak 'нова людина, прибулець'; Nowotny < nowotny 'нова людина'; 'той, що приймає нову віру'; Podruzny, Podruźny < podróżny 'подорожній'; Stroń, Stronczak, Struń <stron-: 1) strona 'сторона'; 2) stronić 'відгороджувати'; 3) заст. ustroń 'затишне місце' (Abuzarova 221); Struk <strukać 'крукати 'видавати звук, подібний до журавлиного'.

\section{Прізвища з основами на позначення родинних стосунків}

Бабкевич / Babkiewicz < babka 'баба, бабуся'; Дзядик, Дзядук, Dziadecki < dziad 'дід'; dziadek 'дідусь, дідунь'; Matkiewicz < matka 'мати'; Swatkiewicz < swat / swatek 'сват'.

\section{Прізвища, похідні від апелятивів з неособовим значенням}

Такі прізвища утворені шляхом метафоричного перенесення реалій дійсності на особу. За походженням це індивідуальні прізвиська, що були дані особі в різні періоди ії життя і за різних обставин. Більшість із них своїм корінням сягає ще праслов'янської доби, навіть інколи праіндоєвропейської, і належить до традиційного народного побутового іменника відапелятивних власних імен, які давали за якимись забобонними мотивами новонародженим дітям як у дохристиянські часи, так і після запровадження християнства аж до XVIII ст. (Железняк 112).

На думку I. Фаріон, «головним критерієм належності відповідних антропонімів до відапелятивних особових власних імен, а не до вуличних прізвиськ $є$ їхнє загальнослов'янське поширення; відповідні порівняльно- 
етнографічні дані різних слов'янських і неслов'янських народів; синхронна і діахронна поширеність та повторюваність досліджуваних антропонімів; масовість та продуктивність, що вказує на глибоке генетичне коріння цих антропонімів та звичай їх надавати» (Фаріон 125).

Прізвища, похідні від неособових апелятивів, ономасти трактують по-різному. Польська дослідниця І. Митнік, дотримуючись запропонованого Й. Бубаком підходу до групування прізвищ, кваліфікує їх як характеристичні (określenia charakteryzujące), не розмежовуючи антропоніми, співвідносні з особовими та неособовими апелятивами (Mytnik 251).

Встановити те особове значення, завдяки якому неособовий апелятив став прізвищем, майже неможливо, оскільки процес такої номінації майже ніколи не обходився без гри фантазії (Чучка, Антропонімія 409). Дотримуючись підходу П. Чучки, з метою уникнення суб'єктивізму класифікуємо прізвища, похідні від неособових апелятивів, за прямим значенням їхніх твірних основ.

\section{Прізвища, основи яких утворені від назв тваринного світу}

Прізвища цієї групи утворені від назв ссавців (Baranowicz, Cielenkiewicz, Wilczek), птахів (Bazantowicz, Czayka, Gawron), риб (Dubielewicz, Piskorz), комах (Czerwiecki, Kleszcz, Dziuk), плазунів (Zmyiewski). До апелятивів твірних основ входять як назви різних видів тварин, так і загальні назви категорій (Rybowicz, Dziubik, Puchowicz).

Шнег <śnieg 'назва птаха'; Baźantowicz < bażant 'фазан'; Byczkow, Byćkiewicz < byk 'бик'; пор. демінутив byczek; Czaykewicz < czajka 'чайка'; Czerwak, Czerwakowna < czerwak 'личинка'; Dziczek < демінутива dziczek (так називали відлюдника, самітника); Dziubik, Dziubig < dziób (dziub) 'дзьоб'; Gawron < gawron / грак 'птах родини ворон'; Kocur < kocur 'кіт'; Kokosz < kokosza 'курка, квочка'; Konik < konik 'коник'; Kotowicz < kot 'кіт'; Kozłowicz < kozioł 'козел'; Kruczykowa < kruczek 'малий крук'; Kunikow, Kunkiewicz - від основи kun-: 1) kuna / куниця 'хижий ссавець' 2) діал. кипіk / кролик; Packan < pac / пацюк 'вид гризуна'; Piskorz, Piskorsz < piskorz 'риба в'юн'; Popiel < popiel 'вид лиса з попелятою шерстю на грудях'; Sikora < sikora / синиця 'птах з роду горобцеподібних'; Skowron < skowron 'жайворонок'; Szczygiel, Sczygieł < szczygieł / щиглик 'птах родини в'юркових'; Wilczek < wilk 'вовк'; Wrobel, Wrubel < wróbel 'горобець'.

Kawka - 1) ап. kawka / галка 'птах з родини ворон'; 2) демінутив ап. kawa (хоча кава прийшла в Європу лише на поч. XVI ст., а в Польщу під кінець XVII ст., на межі XVIII-XIX ст. стала досить популярною, що й засвідчують похідні kawowy, kawiarnia, kawiarka) (Abuzarova 205).

\section{Прізвища, основи яких утворені від назв рослин}

Як і в групі апелятивних назв тварин, тут зафіксовані прізвища, основи яких утворені від видової назви (Groch, Cybulski) і назв категорій (Drewniak, Krzaczkowski, Grzybczyńska тощо). 
Mex < mech 'мох'; Bukowna < buk 'бук'; Chunia - можливо, від chunia 'соснове гілля'; Drewniak < drzewo 'дерево' або drewno 'деревина'; Dziczka, Dziczkowa < dziczka / дичка 'нещеплене плодове дерево'. Могло позначати «дику дівчину» (Abuzarova 208); Groch < groch 'горох'; Gruszka, Gruszkiewicz < grusza 'груша'; Perczak < perczak 'groch polny' / польовий горох; Zielonka, Zielonkiewicz < zielonka: 1) свіжоскошена трава, яку використовують як корм'; 2) зеленушка 'їстівний гриб'.

\section{Прізвища, утворені від назв артефактів}

Артефакт (від лат. «штучно створений») в широкому значенні цього слова - предмет, явище, процес, що є продуктом цілеспрямованої людської діяльності. У цій групі виділяємо прізвища, що походять від назв: продуктів харчування і страв (Barszczyk, Bułkiewicz, Cybulski, Serwatka), предметів побуту (Koszykewicz, Mydło, Zygarek), знарядь праці (Kociuba, Cepuchow, Motykiewicz), одягу та прикрас (Czapkiewicz, Koralowicz, Szubowicz) тощо.

Прізвища, твірні основи яких утворені від назв продуктів харчування чи інших назв, подекуди можуть бути тісніше пов'язані з професіями чи заняттям. Складно з'ясувати, наприклад, чи Bułkiewicz випікав хліб, торгував хлібом чи просто любив їсти хліб; Browarski був власником пивоварні, працював у пивоварні чи любив пиво тощо.

Barszczyk, Barszczykiewicz < barszcz, що позначає кілька понять: із XVIII ст. - 'страва'; пізніше - 'рослина борщівник'; Buńdzio, Bundzio - від основи bund-: 1) bundz 'овечий сир'; 2) bunda 'вид куртки'; Sadło, Sadłowski < sadło 'сало'; Cepuchow < сер / ціп 'знаряддя для молотьби'; Czapkiewicz < czapka / шапка; Duda, Dudziak, Dudzikiewicz, Dudowicz < duda, на сьогодні $d u d a$ / волинка 'музичний інструмент'. Можливо, 'той, хто грає на волинці'; Galarski < galar 'річковий човен'; Grzynda, Grynda < старопол. grzęda 'грядка'; Hakowna <hak 'гак' або hakać 'підгортати'; наприклад, підгортати картоплю; Harak, Harakowa <arak / арак 'вид алкогольного напою' або < harować 'важко працювати'; Kocielski < старопол. kociet (пол. kocioł) 'котел'; Kociuba < kociuba / кочерга 'знаряддя для вигрібання попелу з печі'; Kolenda < kolęda / коляда 'церковна різдвяна пісня'; Koralowicz < koral, koralik 'намистина'; Korytko < koryto / корито 'подовгаста посудина для годівлі худоби'; Kuszel < kusz / кувшин 'посудина для пиття'; Mydło, Mydłowicz < туdło 'мило'; Onuczkiewicz < старопол. описza (тепер описа) / онуча 'шматок таканини, яким обмотують ноги перед взуванням'; Serwatka, Servatka, Serwatkiewicz < serwatka / сироватка 'плазма молока, що виходить під час його переробки на сир'; Skiba, Skibowna < skiba / скибa 'шматок чогось'; Sochinka < socha / соха 'знаряддя для орання землі'; Strug <strug: 1) рубанок 'теслярський інструмент для стругання дерева'; 2) річний човен'; Szydłowicz < szydło / шило 'груба голка'; Żur < żur, żurek / жур, журек 'різновид супу, заправлений квасом з борошна'; Zygarek < старопол. zygarek < zygar (сучасне zegar) / годинник. 
Ці та інші антропоніми засвідчують значний відсоток полонізмів у прізвищевій системі міста. Зважаючи на історичну ситуацію в регіоні, цілком справедливо, що в антропоніміконі м. Луцька, після власне українського, чи не найбільший за обсягом польський компонент.

Висновки та перспективи досліджень. Отже, польські відапелятивні прізвища репрезентують різноманітні твірні основи, за якими виокремлюємо й різні лексико-семантичні групи. Польські прізвища (як і українські) жителів м. Луцька безпосередньо відображають реалії тогочасного суспільства, в якому вони виникли та функціонують як головний засіб офіційної ідентифікації родини в суспільстві. Наше дослідження ще раз підтверджує, що власні особові назви зумовлені історично, що вони зберігають інформацію про історію, культуру, традиції, спосіб проживання народу тощо. І засвідчує взаємний вплив української й польської мов на антропонімікон міста.

Перспективним вбачаємо подальше дослідження відапелятивних та відонімних польських прізвищ, які відтворюють особливості життя лучан, пов'язане з різними культурами, мовами, віросповіданням.

\section{Список використаної літератури}

Горпинич, Володимир, і Корнієнко, Ірина. Антропонімія Дніпровського Припоріжжя $i$ суміжних регіонів України. Дніпропетровськ; Миколаїв, 2006.

Желєзняк, Ірина. Слов'янська антропоніміка. Київ: Кий, 2011.

Редько, Юліан. Словник сучасних українських прізвищ. В 2 т. Львів, 2007.

Словарь української мови, за ред. Б. Д. Грінченка. В 4 т. Київ, 1907-1909.

Совтис, Наталія. «Вплив української мови на формування лексичного складу польської мови XIX ст.». Наукові записки Національного університету «Острозька академія». Серія «Філологічна», вип. 19, Острог, 2011, с. 347-54.

Украӥнсько-польський, польсько-український словник, уклад. М. Юрковський, В. Назарук. Київ: Школа, 2003.

Фаріон, Ірина. Українські прізвищеві назви Прикарпатської Львівщини наприкінці XVIII - початку XIX століття (з етимологічним словником). Львів: Літопис, 2001.

Худаш, Михайло. 3 історії української антропонімії. Київ: Наукова думка, 1977.

Чучка, Павло. Антропонімія Закарпаття. Ужгород: Папірус, 2008.

Чучка, Павло. Прізвища закарпатських українців: історико-етимологічний словник. Львів: Світ, 2005.

Шевельов, Юрій. Історична фонологія української мови. Переклад з англійського видання С. Вакуленка та А. Даниленка. Харків: Акта, 2002.

Abuzarova, Marta. Polskie nazwiska mieszkańców Drohobycza końca XVIII i poczq̨tku XIX wieku na tle wschodniosłowiańskim. Poznań, 2014.

Łesiów, Michał. "Historia wzajemnych kontaktów i wpływów języka polskiego i ukraińskiego". $Z$ badań nad polsko-ukraińskimi powiq̨zaniami językowymi, pod red. D. Buczki, M. Łesiowa. Lublin, 2003, s. 11-23.

Mytnik, Irena. Antroponimia Wołynia w XVI-XVIII wieku. Warszawa: Uniwersytet Warszawski, 2010.

Rymut, Kazimierz. Nazwiska Polaków: słownik historyczno-etymologiczny. W 2 t. Kraków, 1999, 2001.

Taszycki, Witold. Słownik staropolskich nazw osobowych. W 7 t. Wrocław, 1966-1987.

Tomczak, Lucyna. Słownik odapelatywnych nazwisk Polaków. Wrocław, 2003. 


\section{References}

Horpynych, Volodymyr, and Korniienko, Iryna. Antroponimiia Dniprovskoho Pryporizhzhia $i$ sumizhnykh rehioniv Ukrainy. Dnipropetrovsk; Mykolaiv, 2006.

Zheliezniak, Iryna. Slovianska antroponimika. Kyiv: Kyi, 2011.

Redko, Yulian. Slovnyk suchasnykh ukrainskykh prizvyshch. 2 vols. Lviv, 2007.

Slovar ukrainskoi movy, edited by B. D. Hrinchenko. 4 vols. Kyiv, 1907-1909.

Sovtys, Nataliia. "Vplyv ukrainskoi movy na formuvannia leksychnoho skladu polskoi movy XIX st". Scientific Notes of Ostroh Academy National University: Philology Series, iss. 19. Ostroh. 2011, pp. 347-54.

Ukrainsko-polskyi, polsko-ukrainskyi slovnyk, edited by M. Yurkovskyi, V. Nazaruk. Kyiv: Shkola, 2003.

Farion, Iryna. Ukrainski prizvyshchevi nazvy Prykarpatskoi Lvivshchyny naprykintsi XVIII pochatku XIX stolittia (z etymolohichnym slovnykom). Lviv: Litopys, 2001.

Khudash, Mykhailo. $Z$ istorii ukrainskoi antroponimii. Kyiv: Naukova dumka, 1977.

Chuchka, Pavlo. Antroponimiia Zakarpattia. Uzhhorod: Papirus, 2008.

Chuchka, Pavlo. Prizvyshcha zakarpatskykh ukraintsiv: istoryko-etymolohichnyi slovnyk. Lviv: Svit, 2005.

Shevelov, George. A Historical Phonology of the Ukrainian Language. Translated by S. Vakulenko ta A. Danylenko. Kharkiv: Akta, 2002.

Abuzarova, Marta. Polskie nazwiska mieszkańców Drohobycza końca XVIII i początku XIX wieku na tle wschodniosłowiańskim. Poznań, 2014.

Łesiów, Michał. "Historia wzajemnych kontaktów i wpływów języka polskiego i ukraińskiego”. $Z$ badań nad polsko-ukraińskimi powiq̨zaniami językowymi, pod red. D. Buczki, M. Łesiowa. Lublin, 2003, s. 11-23.

Mytnik, Irena. Antroponimia Wołynia w XVI-XVIII wieku. Warszawa: Uniwersytet Warszawski, 2010.

Rymut, Kazimierz. Nazwiska Polaków: słownik historyczno-etymologiczny. W 2 t. Kraków, 1999, 2001.

Taszycki, Witold. Słownik staropolskich nazw osobowych. W 7 t. Wrocław, 1966-1987.

Tomczak, Lucyna. Słownik odapelatywnych nazwisk Polaków. Wrocław, 2003.

Стаття надійшла до редколегії 16.08.2019 